Mieczysław Gajos

Uniwersytet Łódzki

\title{
Urszula Paprocka-Piotrowska \\ CONSTRUCTION DU RECIT DANS LA COMMUNICATION EN LANGUE ETRANGERE
}

LUBLIN: WYDAWNICTWO WERSET, 2013, STR. 309.

Urszula Paprocka-Piotrowska jest naukowcem o uznanym dorobku badawczym, w którym dominują rozważania na temat teoretycznych i pragmatycznych aspektów związanych z procesem przyswajania języków, zarówno ojczystego jak i języków obcych.

Najnowsza monografia Autorki, Construction du récit dans la communication en langue étrangère to dzieło systematyzujące jej dotychczasowe osiągnięcia badawcze poświęcone akwizycji języka. Jest to jednocześnie książka wnosząca wiele nowych cennych spostrzeżeń i obserwacji opartych na bardzo rzetelnie przeprowadzonych najnowszych badaniach, których wyniki pozwalają lepiej zrozumieć istotę procesów powiązanych z nabywaniem umiejętności posługiwania się określonym systemem znaków językowych.

Ta francuskojęzyczna, niezmiernie ciekawa i wartościowa publikacja Urszuli Paprockiej-Piotrowskiej poświęcona analizie tworzenia opowiadania w trakcie komunikowania się w języku obcym doskonale wpisuje się w europejskie i światowe badania psycholingwistyczne, zarówno te teoretyczne jak i aplikatywne, które zmierzają do wyjaśnienia roli procesów poznawczych w nabywaniu określonych kompetencji komunikacyjnych. Opublikowana w 2013 roku monografia Urszuli Paprockiej-Piotrowskiej ma wymiar zarówno poznawczy jak i praktyczny, co z pewnością może sprzyjać poszerzeniu kręgu jej ewentualnych odbiorców. W moim przekonaniu, książka stanowi cenne źródło informacji zarówno dla osób zajmujących się problematyką przyswajania 
języków z punktu widzenia psycholingwistycznego jak i nauczycieli języków obcych, szukających odpowiedzi na pytania związane z optymalizacją procesu przyswajania języka obcego w warunkach szkolnych. Chociaż w swoim najnowszym opracowaniu Autorka ogranicza rozważania do sprawności narracyjnych w języku, to można tu także odnaleźć refleksje i opinie dotyczące nabywania ogólnej kompetencji językowej i komunikacyjnej, skuteczności porozumiewania się czy metodologii prowadzenia badań dotyczących akwizycji języka.

Urszula Paprocka-Piotrowska systematycznie, w sposób przejrzysty i uporządkowany wprowadza czytelnika w teoretyczne i pragmatyczne zagadnienia dotyczące tekstów narracyjnych, konstruowania opowiadania jako czynności metajęzykowej i językowej oraz nabywania przez uczących się języka umiejętności narracyjnych przy użyciu kodu języka drugiego/obcego.

Książka dostarcza również ciekawego materiału pozwalającego na obserwację warsztatu metodologicznego wykorzystanego przez Autorkę, którego opanowanie jest niezbędne do prowadzenia rzetelnych badań nad przyswajaniem języka. Z tego względu monografia Urszuli Paprockiej-Piotrowskiej może stanowić cenne źródło inspiracji dla psycholingwistów, językoznawców i glottodydaktyków parających się badaniami nad asymilacją języków obcych. Może również dostarczać młodym badaczom i studentom cennych wskazówek na temat sposobu organizacji i prowadzenia badań nad akwizycją języka.

Dzieło, które liczy w sumie 309 stron zostało podzielone na cztery rozdziały, poprzedzone uwagami wprowadzającymi, zakończone konkluzją końcową, po której zamieszczono bardzo obszerną, wielojęzyczną bibliografię przedmiotu, streszczenie w języku angielskim, (szkoda, że zabrakło streszczenia w rodzimym języku Autorki), oraz indeks pojęć.

Wychodząc od znanych i powszechnie uznawanych teorii analizy tekstów narracyjnych, (Barthes, Genette, Adam, Labov, Waletzky i inni), Autorka w sposób syntetyczny i krytyczny zaprezentowała na łamach pierwszego rozdziału swojej monografii własną próbę zdefiniowania tekstu narracyjnego, wskazała na typowe cechy narracji oraz szczegółowo opisała wewnętrzną strukturę tekstów o charakterze narracyjnym. Uczyniła to z punktu widzenia ucznia, który nabywa i kształtuje językowe kompetencje komunikacyjne w języku obcym. Od samego początku, Autorka umiejętnie łączy teorię z praktyką, co widać wyraźnie poprzez całą sieć umiejętnie dobranych przykładów, które posłużyły do zilustrowania omawianych w tym rozdziale zagadnień.

Podobnie jest w rozdziale II, który został w całości poświęcony analizie czynności narracyjnej ucznia przyswajającego sobie język obcy. Autorka prześledziła i precyzyjnie opisała mechanizmy i strategie wykorzystywane przez ucznia-narratora do tworzenia wypowiedzi w języku obcym, które noszą cechy 
opowiadania. Słusznie zauważa, że ucząc się języka obcego, uczeń powinien potrafić optymalnie korzystać z wcześniej nabytych i zinterioryzowanych umiejętności w języku rodzimym, w tym posiadanych kompetencji narracyjnych. Posiadane przez ucznia kompetencje dyskursywne opanowane w trakcie akwizycji języka pierwszego mogą i powinny być wykorzystywane na zasadzie pozytywnego transferu do samodzielnego tworzenia tekstu narracyjnego przy zastosowaniu obcojęzycznych środków językowych, nawet tych dość ograniczonych.

Omówione teoretyczne zagadnienia dotyczące konstruowania opowiadania w języku obcym zostały bogato zilustrowane i poparte odpowiednio przytoczonymi przykładami, co wpływa na przejrzystość i lepsze zrozumienie prowadzonego wywodu.

W dwóch pierwszych rozdziałach, otrzymaliśmy zatem spójne autorskie podejście teoretyczne dotyczące tekstu narracyjnego i jego tworzenia w trakcie procesu przyswajania języka obcego, które umiejętnie łączy wcześniejsze teorie semiotyczne, psycho i socjolingwistyczne ze spojrzeniem funkcjonalnym dokonywanym w perspektywie glottodydaktycznej.

Od teorii do praktyki, taka jest koncepcja książki dr hab. Urszuli Paprockiej-Piotrowskiej, która swoje rozważania teoretyczne zawarte w dwóch pierwszych rozdziałach monografii uzupełniła kolejnymi dwoma rozdziałami o charakterze empirycznym. Znajdujemy tutaj szczegółowe opisy i wyniki przeprowadzonych badań własnych, które ukazują w jaki sposób uczący się języka obcego nabywają kompetencję narracyjną. Dużą wartość rozdziałów III i IV upatruję w ich wymiarze metodologicznym. Dostarczają bowiem czytelnikowi istotnych informacji na temat procedur i narzędzi badawczych niezbędnych do prowadzenia rzetelnych badań z zakresu akwizycji języka, o czym wspomniałem już wcześniej.

Podsumowując, najnowsza monografia dr hab. Urszuli Paprockiej-Piotrowskiej stanowi bardzo ciekawe studium teoretyczno-pragmatyczne poświęcone nabywaniu kompetencji narracyjnej w języku obcym, wnosi wiele ciekawych obserwacji i spostrzeżeń do omawianej tematyki i to zarówno z punktu widzenia merytorycznego jak i metodologicznego. Gorąco polecam tę pozycję nie tylko naukowcom zajmującym się zagadnieniami przyswajania języków, ale również nauczycielom języków obcych i studentom neofilologii. Mam nadzieję, że język publikacji - francuski - nie będzie przeszkodą w jej odbiorze przez innych neofilologów. Zamieszczone streszczenie w języku angielskim i wielojęzyczna bibliografia mogą być pomocne dla osób, które nie znają języka francuskiego. 